\title{
Retrospectiva de Beatriz González en el CAPC de Burdeos. La perseverancia del baobab
}

\author{
Beatriz González (1965-2017) \\ CAPC, Musée d'Art Contemporain de Bordeaux \\ Del 23 de noviembre de 2017 al 25 de febrero de 2018
}

De entre muchas de las prácticas habituales que caracterizan la obra de Beatriz González el nomadismo constituye un principio de activación. El trasiego no se trata tanto de un ejercicio físico y trascendental, como podría significar para Benjamin o Werner Herzog, sino como una canalización o un mecanismo mental con el que hacer converger ideas de distintos contextos. Para la artista colombiana (Bucaramanga, 1936), las imágenes fluyen en su trabajo independientemente del rango o el valor que les otorgue el lugar del que procedan, aunque finalmente estas evoquen en sus pinturas un clima o un tono específico. Con frecuencia podemos encontrar en su obra la convergencia de conceptos o temas antagónicos, que bien podría recordar a la apertura de La mansión de Araucamía, del también colombiano Álvaro Mutis. «Le faltaba un brazo y hablaba correctamente cinco idiomas. Olía a esas plantas dulceamargas de la selva que, cuando se cortan, esparcen un aroma de herida vegetal». El desplazamiento y la regeneración, como situaciones que impiden a un individuo permanecer en el área de confort, suponen para la pintora los condicionantes necesarios para reinventarse como artista, o al menos para posibilitar nuevos procesos y resultados originales.

González suele reunir en su pintura elementos que en un principio podrían parecernos incompatibles; como la violencia omnipresente y el humor o la ética y la cultura popular con la abundancia de la naturaleza. Tras sesenta años de dedicación al arte desde la producción pictórica al comisariado, la crítica y la enseñanza artística, llega su primera gran retrospectiva a nivel internacional en el marco del Año Francia-Colombia 2017, en coordinación con el KW Institute for Contemporary Art de Berlín y el Museo Nacional Centro de Arte Reina Sofía. El escenario, nada más y nada menos que el CAPC de Burdeos, un museo de arte concebido sobre el Entrepôt de la Place Lainé, antiguo depósito de ultramarinos en el que ya expusieron artistas relevantes como Keith Haring, Barceló, Kapoor o Kiefer.
La exposición está compuesta por unas 130 obras que reflejan de forma parcial la trayectoria de González, dejando claro que gran parte de su investigación ha sido teórica y pedagógica y acordando por esta razón que muchas de sus aportaciones resultarán difíciles de apreciar.

Tratándose de una retrospectiva convendría que analizáramos en primer lugar uno de los episodios que con mayor fuerza marcó a la creadora, siendo consecuentemente uno de los puntos de inflexión en su carrera artística y en su visión plástica. El suceso lo recogió el periódico El Espectador, pero no fue a través de este medio como González conoció la noticia sino por una fotografía de la misma publicada por la competencia, el diario El Tiempo. En la imagen aparecían un jardinero y una empleada de servicio en actitud cariñosa y sosteniendo entre ambos un ramo de flores. El titular sin embargo era trágico, la pareja había decidido suicidarse en la laguna del Sisga para escapar de los males y el terror de una sociedad que, según el jardinero, ensombrecería el amor que se profesaban ambos.

La pintora decidió utilizar esta fotografía para la realización de una obra que más tarde presentaría al XVII Salón Nacional de Artistas de 1965. El rechazo inicial que provocó su propuesta entre los espectadores se debió en gran parte a la excéntrica elección del tema que motivó su pintura, pero finalmente el jurado le otorgó un premio especial. González tituló esta obra Los suicidas del Sisga [1]. Para la creadora las imágenes comparten un mismo estatuto, independientemente del lugar del que sean tomadas, siendo en el caso de la pareja protagonista una imagen reproducida a partir de otra publicada anteriormente. Puede resultar estimulante reflexionar sobre esta apuesta plástica teniendo en cuenta además la teoría de Hito Steyerl sobre la naturaleza de las «imágenes-pobres», según la cual, su configuración las releva a jerarquías inferiores. La mala reproducción que publicó El Tiempo, en la que los tonos habían sido aplanados por el 


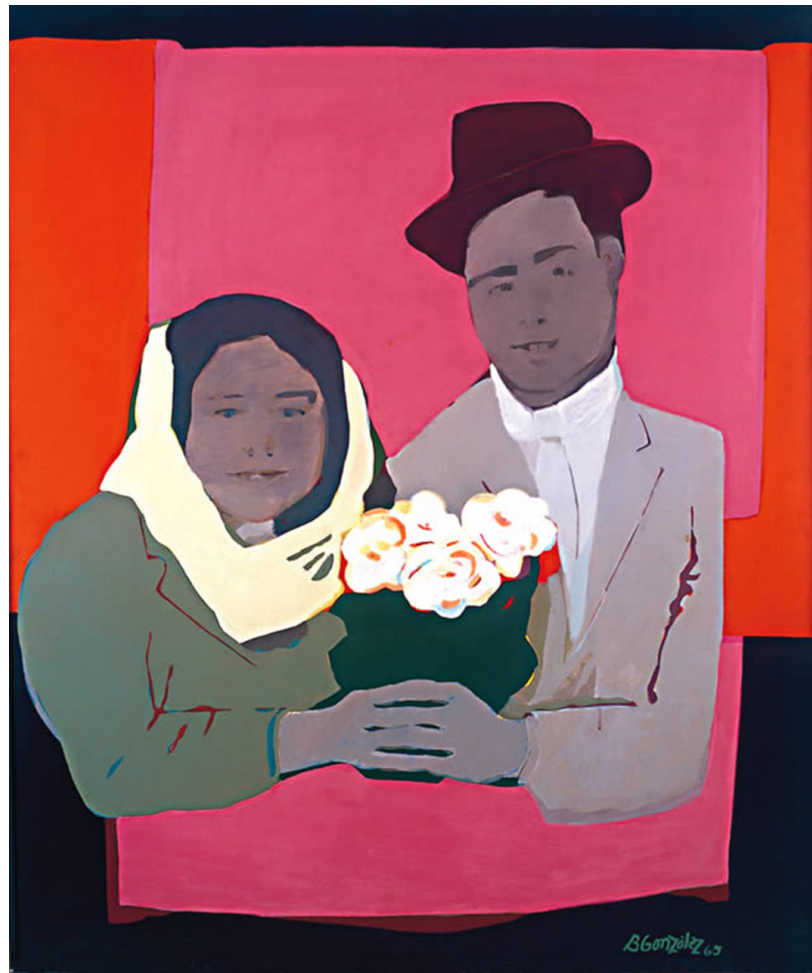

1. Beatriz González, Los suicidas del Sisga 2. Óleo sobre lienzo, $120 \times 100 \mathrm{~cm}, 1965$

agrisado de la fotografía, le permitió a la autora colombiana apreciar las inagotables posibilidades que este resultado estético tendría en su propio proceso artístico.

Son muchas las referencias que hace a la cultura occidental y a la historia del arte, aunque en un principio pudiéramos aproximar su pintura a referentes del pop americano. Sin embargo, su discurso político y las continuas referencias al folklore nacional le han definido como una «pintora de provincia», que es la visión que González nos da de sí misma. En este sentido, su imaginario ha contemplado la realidad específica o regional que reflejaban los medios de comunicación colombianos para alcanzar finalmente una dimensión universal, traspasando cualquier barrera cultural o estilística. Es a través de la observación de la cultura kitsch y popular como construye su pintura, generalmente agrupada a través de series temáticas y con un profundo carácter narrativo. Quizá esto último sea una herencia tomada de aquellos artistas que le influyeron en su juventud, como fueron Vermeer de Delft -del cual hizo un estudio minucioso sobre La enca- jera-, Leonardo, Boticelli o Velázquez. A pesar de la reiteración temática, recordando por caso sus diferentes versiones de Los suicidas del Sisga (1965), Las delicias (1998), o Los ahogados (a la que pertenece La pesca milagrosa, 1992) [2], González evitó el amaneramiento con el objetivo de sentir en todo momento la originalidad y la autenticidad en su pintura.

Otro de los factores que destacan en su trayectoria es el compromiso social y político, aunque en su primera etapa de formación demostrara un cierto desapego o una imparcialidad por los temas sociales que trasladaría a sus cuadros. La neutralidad con la que realizaba sus primeras pinturas se debía al rechazo generalizado que demostraban los estudiantes de arte por el compromiso político, distanciándose de otros artistas latinoamericanos que habían alcanzado la fama precisamente por su posicionamiento crítico. Por otro lado, su interés se centraba entonces por completo en el conocimiento estético de las formas y el análisis del color, a lo que también deberíamos añadir un indiscutible sentido del humor. La tragicomedia ha sido, por ejemplo, uno de los recursos de los que se ha servido para interpelar al público y también para ironizar sobre ciertos personajes de la política como presidentes o ministros (Apuntes para la historia extensa, 1967). En cierta manera, esta serie podría recordarnos a los Tanguillos del Golpe que cantaba Juan Palacios para ridiculizar a Tejero.

Mientras que en Los suicidas del Sisga la dicotomía se establecía entre la escena ceremoniosa de la pareja y el trágico desenlace reflejado en el título, el capítulo histórico que su país sufriría con el incidente de 1985, en el que los guerrilleros de la M-19 accedieron al Palacio de Justicia para incriminar a Betancur el cese del Acuerdo de Paz, condujo a la artista a una etapa más sobria y dramática debido a la tragedia del incendio en el que derivó este asalto.

Si observamos la totalidad de su trabajo en estos 60 años, podemos evidenciar las continuas incursiones y desplazamientos hacia áreas con las que la autora no estaba familiarizada, como puede ser la serigrafía o el uso de la pintura sobre objetos ordinarios. Un buen ejemplo puede ser su obra Áuras anónimas, realizada en 2009 en el Cementerio Central de Bogotá y en el que ya es una obviedad su compromiso con la memoria colectiva del país. Esta acción se puede contemplar en el CAPC gracias a un documental que se grabó con motivo de la intervención en los cuatro columbarios del cementerio. 


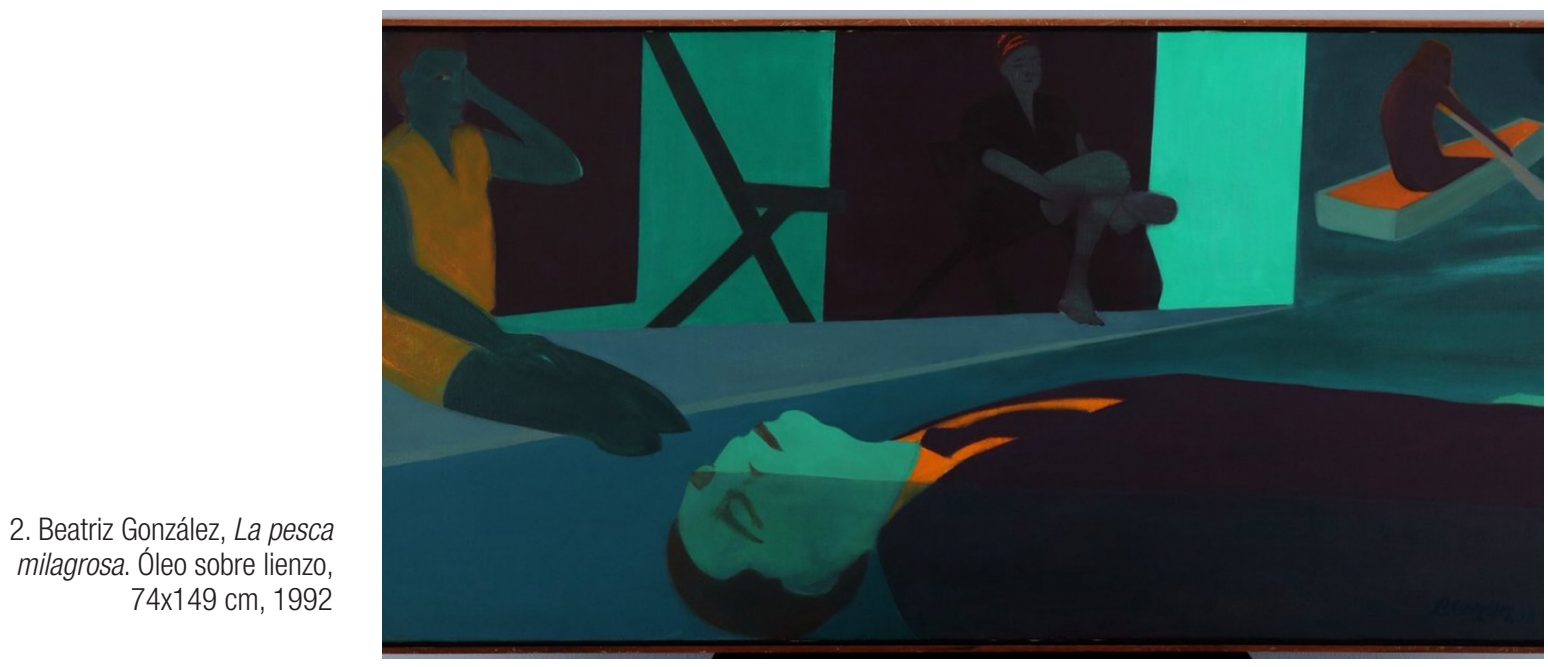

A partir de los años 70 González comenzó a intervenir cabeceros y otros mobiliarios sobre los que pintaba o añadía nuevos resultados, dejando entrever en ellos sus prestaciones de pintores como Braque, Renoir o Picasso. A través de estos objetos podía descubrir los gustos populares de un modo que bien podría recordar a lo que escribía Carlos Marzal en su Cuaderno del Polizón: «[...] los muebles son formas vivientes, pensantes, sufrientes. A su manera, claro está, pero todo lo dicho. Yo los llamo para mis adentros las criaturas muebles».

Sin ninguna duda, la exigencia de la autora por mantenerse en arenas movedizas la han llevado a situarse como una de las artistas latinoamericanas con mayor proyección, transmitiendo con sus pinturas toda una cultura de iconos y de tradiciones que con justicia podrían equipararla a figuras como García Márquez, Tamayo o Roberto Matta.
Desde hace unos años existe en Medellín una problemática en el barrio El Poblado, teniendo como protagonista a un extraño baobab de cuarenta metros del que nadie conoce su origen. Es un tipo de árbol que suele encontrarse tan solo en las sabanas de África, por lo que resulta muy sorprendente su capacidad de adaptación al terreno. Uno de los vecinos del barrio, cuya casa colinda con el baobab, decidió poner a trámite la ampliación de su hogar, motivo por el que pidió la tala de este extraño árbol, aunque afortunadamente el vecindario se lo ha impedido hasta ahora. Aunque sea razonable el nomadismo, como se empeña González en cada una de sus nuevas pinturas, no deja de sorprender que a veces los hallazgos dejen de lado la lógica por momentos. 